\title{
Discussion on the improvement of teaching quality from the teaching reform of "Animal Quarantine Technology"
}

\author{
Zexiao Yang ${ }^{a^{*}}$, Yin Wang ${ }^{b}$, Xueping $\mathrm{Yao}^{\mathrm{c}}$ and Zhiwen $\mathrm{Xu}^{\mathrm{d}}$ \\ Sichuan Agricultural University, Chengdu China, 611130

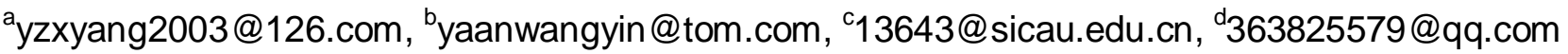 \\ *The corresponding Author
}

Keywords: Animal quarantine technology; Teaching reform; Teaching quality; Study

\begin{abstract}
To improve the teaching quality of "Animal Quarantine Technology" course. According to the "national long-term education reform and development plan (2010-2020)" and combining the development status and social demand of the major of animal and plant quarantine, the teaching reform exploration of "Animal Quarantine Technology" was carried out in recent 6 years which including specialty construction, course construction, teaching innovation by means of revising and improving the syllabus on the course nature, determining the teaching content, optimizing teaching methods and improving the course evaluation system based on the analyzing the current opportunities and challenges of higher education, and the teaching reform experience and teaching results were summarized. The results showed the course teaching reform was benefit for the improvement of the teaching quality and it had good teaching effect with a above $95 \%$ attendance rate and above $99 \%$ teaching satisfaction online evaluation. All these results suggested that the leading role of teachers is the key to the reform of higher education, especially in the teaching reform process of the professional courses of technical nature. the scientific quality view is the necessary condition for the success of the reform of higher education and teaching. This provides an important reference for the reform of higher education in China.
\end{abstract}

\section{Introduction}

Since the national college enrollment expansion in 1999 , the cultural quality of the whole nation has been obviously improved, and the level of education structure was more optimized. However, with the further development of the world multipolarization and economic globalization, scientific and technological progress, and increasingly fierce competition for talent, the students capacity for adapting to the social and employment is not strong, and the innovative, practical, and complex talent shortage have become the grim reality of China's economic development, especially in the higher education. How to ensure and improve the quality of personnel training to meet the needs of social and economic sustainable development gradually become the central issue of the development of higher education in China. So is the education of veterinary medicine class. Many important animal epidemics and the veterinary public hygiene events such as "SARS event" (2002) [1], "HPAI event" (2004) [2], "swine streptococcus type 2 event" (2005) [3], "PPR epidemic " (2007) [4] and "melamine event" (2008 [5], occurred in China in the beginning of twenty-first Century's, let us realize the importance and urgency of improving the consciousness of veterinary public hygiene and training qualified professionals and innovative talents. The education quality improvement depends on education development, education development relies on education reform[6]. The "national long-term education reform and development plan (2010-2020)" (hereinafter referred to as the "education plan") promulgated in 2010 in China and "the undergraduate teaching quality and teaching reform project" implemented in 2011 supplied the guidance and basis for the higher education teaching reform in China. Strengthening professional construction and improving teaching quality through the reform of teaching content and teaching methods, and exploration and construction of modern school system and innovative personnel training system have become important research projects of educational reform and innovation and received widespread attention. 
"Animal Quarantine Technology" takes the methods and technology of animal disease and animal food hygiene inspection and quarantine as the main study contents, which is based on the theory of veterinary medicine and public hygiene. it has a strong professional, comprehensive and practical, and is a specialized course for students majoring in animal and plant quarantine which was established in 2005 on the basis of the investigation and analysis of the needs of the social economic development to the animal medicine talents. In order to improve students' practical ability and quality to adapt to social needs, the teaching reform was carry out by the training plan optimization and the professional construction strengthening on the basis of the early education and curriculum construction, combined with the actual situation of the teaching work.. This paper summarized and analyzed the exploration and practice of "Animal Quarantine Technology" teaching reform in the recent 6 years including course syllabus and content, teaching methods and examination system reform.

\section{Strengthen the Professional Construction, Improve the Curriculums}

With the rapid development of animal husbandry and veterinary industry in China, The problems between social needs and the current situation of the veterinary medicine cultivation are unceasingly appearing. The current situation of animal medicine talents can not meet the needs of the social development of professional and innovative veterinary talents in different directions. The animal and plant quarantine is a new major for professional and innovative veterinary talents education. To strengthen the professional construction and optimize the knowledge structure of students, A lot of investigation and survey were carried out every year according to the actual situation of education and teaching and the changes of social demands, the training plan was revised, the course teaching reform was strengthen on the basis of the basic theory and technology study of veterinary medicine. The "Animal Quarantine Technology" was listed as a specialized course in animal and plant quarantine in 2005. And the "Veterinary Public Hygiene", "Animal Epidemic Prevention and Administration" and "Risk Analysis of Significant Animal Diseases" were listed as the professional elective courses in 2012, a medical professional is more prominent on animal quarantine and quarantine technology requirements.

\section{Attach Importance to Curriculum Construction and Reform}

Take the quality improvement as the core task according to the "education plan" and the spirit of the "teaching quality and teaching reform project of higher education", continue to increase investment in teaching, pay attention to the allocation of educational resources, the education quality and teaching reform. The professional laboratory was established and improved, the teaching reform were carried out led by Professor. Until now, 1 excellent course of the "veterinary hygiene inspection" and 1 high quality and characteristics course of "Animal Quarantine Technology" in Sichuan agricultural university were constructed, 1 education reform project was applied, at the same time the "Animal Quarantine Technology" was constructed as high-quality excellent resources sharing course in the school support.

\section{The Teaching Reform of "Animal Quarantine Technology" Based on the Principle of "Double-Zhu"}

Take the Student as the Main Body, to Revise the Syllabus and Optimize the Teaching Content. Fully grasp the nature of the course and revise the syllabus. The teaching of theoretical knowledge is the basis of students' learning, but the experimental teaching is also an important part of the teaching system of animal medicine specialty and the necessary practical teaching link. And it plays a very important role in improving the quality of the students, which can not be replaced by the theory teaching, and it can not be replaced by the theory teaching[[7,8,9].Therefore, the original syllabus was revised, according to the course of animal quarantine teaching purpose and nature, and based on learning professional training programs and grade courses in the learning situation and 
paying attention to the unity of knowledge and knowledge update. The total teaching hours was modified as 64 from the original teaching hours of 48, theoretical teaching hours was of 40, the experimental teaching hours of the 20 and self-study hours of 4 . So as to ensure the introduction of new knowledge and students' independent innovation space, at the same time, fully grasp the unity of theoretical teaching and improving students' practical ability, as well as the nature of curriculum.

Strengthen the teaching materials construction and arranging the teaching contents reasonably. Teaching material is the reference and basis for teaching. Because there is no national planning for the use of special teaching materials, it is very difficult to set up the teaching content. The teaching group takes the "Modern Inspection and Quarantine Method" and the "11th Five-Year" national planning textbook "Veterinary Public Hygiene " as reference, The teaching contents were divided into three parts, including introduction of animal quarantine, routine animal quarantine methods and modern animal quarantine technology, according to the student's curriculum, the study situation at home and abroad, and the research status and progress of science production practice. At the same time, the experimental teaching materials was constructed according to China's national standards and relevant national laws and regulations, as well as some of the relevant provisions of the international content of experimental teaching.

As the key points of teaching and learning for teachers in the course of teaching, the selection of teaching content will affect the teaching quality of this course. The teaching and research group mainly follow three principles in the arrangement of teaching contents. First is to adhere to the facts and to highlight the key. According to the actual situation of the students choose the teaching contents; do not avoid the important points of knowledge for intensively study. For example, polymerase chain reaction (PCR) detection technology and enzyme-linked immunosorbent assay (ELISA) technology are the important contents of the theory and experiment teaching, although in the "Animal Microbiology and Immunology", "Animal Infectious Diseases" and "Modern Molecular Biology" and other courses had been involved in the study and learning. In this course, we still focus on their strengthening study, to ensure that the professional skills to meet the needs of veterinary professional social work, because the survey found that most of the students to understand the knowledge and technology is limited to the superficial theory. Second, emphasizing the principle of standardization and standardization. The one inspection and quarantine technical operation, although the principle is the same, but there are different methods of operation. We select the national standard operation method and the conventional operation method for comparative teaching; this not only inspires students to understand the theory more deeply, but also strengthens the students' standard operation and standardization consciousness. Third, the principle of contacting the practice of production, to develop students' comprehensive application and innovation ability. In the course of teaching, some animal epidemics or veterinary public health events, which are combined with the production and social reality, are designed. Most students take the initiative to consult the literature collection materials, showing a strong learning enthusiasm and interest.

\section{Giving Full Play to the Leading Role of Teachers, Reforming Teaching Methods and Improving Teaching Efficiency.}

Multimedia teaching plays an important role in theoretical teaching. With the development of scientific research in various disciplines, the new research contents and achievements are constantly emerging, and the teaching materials are also growing bodiness. However, to learn advanced technology, the original basic theory or classical knowledge must not be missing. In this case, there is a contradiction between the increase of teaching content and the same or less teaching hours, and the course teaching of animal quarantine technology is also so. We improved the "Animal Quarantine Technology" CAI courseware through the exquisite resource sharing course construction, and make full use of multimedia teaching, instead of the edge blackboard while teaching in the traditional teaching method, greatly saves the teaching hours, not only to ensure that the provisions of the teaching content, but also can teach more new teaching content. And the use of a number of graphics, animation, images, text and video and other materials to simulate some 
abstract difficult to explain the theory and demonstrate some experimental standard operation and process, to play the vivid image advantages of multimedia teaching.

Strengthen the standard operation and attach importance to the cultivation of students' ability. For any professional, there is no solid theoretical basis and standardize the operation of technology, interest and innovation can not be talked about. In the experiment teaching of "Animal Quarantine Technology", the content of experiment teaching is arranged according to the proportion of "Basic tests $30 \%$, classical tests $30 \%$, new test s $30 \%$ and comprehensive test s $10 \%$, at the same time the patent (see Fig.1) was introduced for teaching. On the basis of the combination of the teaching of multimedia theory, teachers demonstrate and standardize the operation of students, and closely guide the students' experimental training and students' own experiments designed. On the one hand, it is necessary to standardize the operation technology of students and deepen their understanding of knowledge, on the other hand, it leads to students' interest in learning and innovation.

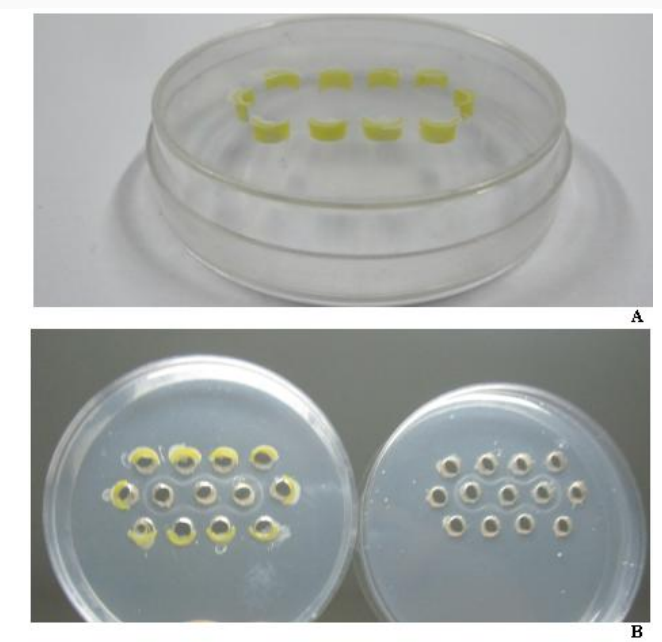

Figure 1. Double agar diffusion test kit and the application result (patent ZL201420642585.2)

Teach students in accordance with their aptitude and encourage undergraduates to participate in scientific research. For those students who have good theoretical knowledge, practical ability and self-learning ability, To carry out the targeted training to encourage them to participate in graduate or doctoral related scientific research projects, and fully explore and play outstanding innovative research resources of the Undergraduates.

\section{Developing a More Reasonable Performance Evaluation System}

In order to better assess the ability of the students and curriculum learning, "a test scores" assessment methods was reformed and the implementation of flexible multi assessment system was established. That is, the course scores includes examination paper test scores (50\%), performance scores $(20 \%$, attendance and seminar in class score of each of the $10 \%)$, experimental scores $(20 \%)$ and others $(10 \%)$. Not only to change a part of college students "guess the focus of exam" error learning concept, and to correct some students opportunism idea of "simultaneous cross curricula-variable at the same time", to correct students' learning attitude and develop good study habits.

\section{Teaching reform Results and Effects}

The effect of professional construction and teaching reform is a long-term effect, it is difficult to have some short-term specific indicators. Nevertheless, a perfect professional training program was formed, graduate students' operation ability is greatly improved, and with a ideal employment rate of graduates and received good social response and approval, through the professional construction and teaching reform in these years. By the teaching reform of "Animal Quarantine Technology" 
course, the attendance rate of students in this course is above $95 \%$, and the satisfaction of online teaching evaluation is up to $99 \%$, and the number of students who ask questions is greatly increased. What's more, it greatly stimulated the initiative of the students. And in the course of graduation thesis in the process of the design of professional students and related to the operation of the quarantine technology is very standardized and skilled.

\section{Conclusion and Discussion}

Although the reform of teaching is not the whole development of higher education, the reform of curriculum seriously affects the effectiveness of professional construction and the quality of personnel training. In the process of teaching reform in the course of "Animal Quarantine Technology", not only the teaching syllabus, teaching content, teaching methods and performance evaluation system were improved, but also the teaching mode of combining professional quality and humanistic quality was explored. By professional teachers will infiltrate moral education into professional quality education, the students' cultural literacy was improve, meanwhile can make students from professional knowledge to learn how to get the truth in the comprehension process, and then set up the world outlook, correct sense of worth, such as the perseverance, and the family and social sense of responsibility. This teaching reform explore does not distract the students to learn professional knowledge, on the contrary, stimulates students' interest in learning professional knowledge and enthusiasm.

Education plans, teacher centered, Good education needs to have a good teacher[6]. We have some experience, that is, the role of teachers in the teaching of higher education and the importance of teachers' selfless pay. In recent years, with China's "higher school undergraduate teaching quality and teaching reform project" full implementation, many educators have done a lot of experiments and explorations on Teaching Reform in different fields according to the professional characteristics $[10,11,12]$. There have been a lot of innovative teaching models and teaching methods, such as heuristic teaching, inquiry teaching, scientific innovative oriented teaching[13], project teaching[14] etc., and have achieved a certain effect. Through the comparative analysis of these teaching reform methods it is not difficult to find, although various teaching models or methods of different characteristics, but the total work amount paid by teachers in teaching reform and teachers' leading role is not reduced. So, the work amounts and the strengthening degree of the leading role of teachers and the mobilization of students' initiative in learning should become the important indexes of the success of teaching reform. This is worthy for consideration in the process of higher education reform in China.

Our country is in the key stage of reform and development, the marketization, internationalization, population, resources and the environment are under increasing pressure, the transformation of economic development mode is accelerating, all of these have highlighted the importance and urgency of improving the national quality and cultivating the innovative talents [6]. We must be aware that, as with animal medicine, the education of all kinds of professional talents is facing unprecedented opportunities and challenges. Therefore, as a teacher, we need to fully understand their own responsibilities for the social, correct morality, willing to advocate good and brave and selfless dedication, and unknown to the public attention, and focus on the combination of knowledge and practice, because this is the key to ensure and correct teaching and educational reform.

\section{Acknowledgements}

This study was supported by Grants from Research project of educational reform in Sichuan Province (2014-156-173).Corresponding author: Yin Wang, Zexiao Yang.

\section{References}

[1] W. Rui, Q.P.Zhang, L.Shi and M.Lu: Progress on the genome and protein and the research 
status of process into the host cell of SARS coronavirus, National Medical Journal of China, Vol.83(2003) No.11, p.913-922. (In Chinese)

[2] Information on http://www.bioon.com/biology/ sars/165472.shtml (In Chinese)

[3] M.Y. Fan: Some problem of streptococcus type 2 disease about swine and people, Disease Surveillance, Vo1.20 (2005)No. 7, p.337-338. (In Chinese)

[4] Information on http://www.ivdc.gov.cn/gg/200901/P020090106537457039975. doc (In Chinese)

[5] Information on http://www.china.com.cn/node_7064072/content_19612595.htm (In Chinese)

[6] Information on http://edu.sina.com.cn/1/2010-07-30/ 0811191352. shtml(In Chinese)

[7] J.N. Liu, X.J. Pan and X.D. Wang: Practice of experimental teaching research and Reform, Experimental Science and Technology, Vol.9(2011) No.4, p.154-156. (In Chinese)

[8] S.Q. Zhang and L. Zhang: Research on the new teaching method of Engineering Specialty in Colleges and Universities, Experimental Science and Technology, Vol.9(2011) No.4, p.62-63. (In Chinese)

[9] Z.X. Yang: Proc. The 7th International Conference on Education, Management, Computer and Medicine (Shenyang, China, Dec 29-31, 2016).Vol.59, p.807-812.

[10]F. Zhou: Taking the student as the main body to innovate the talent training mode, China Higher Education, Vol.8(2011) No.1, p.32-33. (In Chinese)

[11]B. Qu, T. Liu: Innovating teaching management and improving the quality of personnel training, China Higher Education, Vol.8(2011) No.1, p. 39-44. (In Chinese)

[12]Z.X. Yang, Y. Wang, X.P. Yao, K.Y. Wang, Z.W. Xu and L. Zhu: Exploration and experience of teaching reform of Animal Quarantine Technology, Heilongjiang Animal Science and Veterinary Medicine, Vol.427(2013) No.4, p.158-160. (In Chinese)

[13] M. Liu, H. P. Cao and J. Zhou: Exploration and Research on "innovative" electrical experiment teaching mode, Experimental Science and Technology, Vol.9(2011) No.4, p.79-81. (In Chinese)

[14]H. Wang, J.Y. Liu and A. Chen: The application of project guidance mode in the teaching of electrical and electronic experiment, Experimental Science and Technology, Vol.9(2011) No.4, p.74-78. (In Chinese). 